PERM JOURNAL OF PETROLEUM AND MINING ENGINEERING

ВЕСТНИК ПНИПУ. ГЕОЛОГИЯ. НЕФТЕГАЗОВОЕ И ГОРНОЕ ДЕЈО

ISSN 2224-9923

Volume / Tom 17 №1 2018

http://vestnik pstu.ru/geo/

УДК 622.692.4.053:614.8

Article / Статья

(C) PNRPU / ПНИПУ, 2018

\title{
SECURITY OF MAJOR PIPELINES IN PRESENCE OF TERRORISTIC THREATS: PROGNOSTIC ESTIMATES
}

\section{Vladimir A. Komarov, Zinaida V. Semenova ${ }^{1}$, Evgeniy M. Mikhaylov ${ }^{1}$, Aleksey A. Nigrey, Dmitriy A. Bronnikov}

Omsk State Transport University (35 Marksa av., Omsk, 644046, Russian Federation)

${ }^{1}$ Siberian State Automobile and Highway University (5 Mira av., Omsk, 644080, Russian Federation)

\section{БЕЗОПАСНОСТЬ МАГИСТРАЛЬНЫХ ТРУБОПРОВОДОВ В УСЛОВИЯХ ТЕРРОРИСТИЧЕСКИХ УГРОЗ: ПРОГНОЗНЫЕ ОЦЕНКИ}

\section{В.А. Комаров, 3.В. Семенова ${ }^{1}$, Е.М. Михайлов ${ }^{1}$, А.А. Нигрей, Д.А. Бронников}

Омский государственный университет путей сообщения (644046, Россия, г. Омск, пр. Маркса, 35)

${ }^{1}$ Сибирский государственный автомобильно-дорожный университет (644080, Россия, г. Омск, пр. Мира, 5)

Received / Получена: 08.11.2017. Accepted / Принята: 02.02.2018. Published / Опубликована: 30.03.2018

\section{Key words}

major pipelines, terroristic threats, unauthorized tie-in, physical security system, detection reliability, multi-sensor systems, vibroacoustic oscillations, leak detection, security zone, seismic oscillations, object protection costs, oil theft prevention problem, probability of errors of $1^{\text {st }}$ and $2^{\text {nd }}$ kind, economic damage, object security cost.
The purpose of the paper is to substantiate the approach to determining the required probability of detecting unauthorized attempts to contact the pipe shell to maintain a minimum level of pipeline security losses. That is also nesseccerly to assess probability trend in the near future. Based on the information obtained it is planned to propose the structure of the physical pipeline security system to neutralize terroristic attacks. Results of studies of vibroacoustic oscillations in the shell of a major pipeline during its operation are given. The mechanisms of change in parameters of a vibroacoustic pulse excited at a local point of a pipeline when it is propagated through a pipeline are expalined. Results of studies on the solution of the problem of detection and prevention of emergencies in the protected zone by seismic oscillations are considered. It is problem of detection and prevention of emergencies in the protected zone by seismic oscillations are considered. It
concluded that it is possible to detect precursors of emergencies by vibroacoustic and seismic vibrations of the pipe shell. concluded that it is possible to detect precursors of emergencies by vibroacoustic and seismic vibrations of the pipe shell.
The effectiveness of the proposed approach to determine the requirements for systems of protection of objects from terroristic threats is demonstrated. The region was chosen in accordance with available published data for a relatively long period of time, necessary for setting up a computational experiment. It is interesting to receive prognostic estimates in that segment of economy for the country as a whole.

Presence of such information allow creating a policy for detecting terroristic attacks and deciding on the requirements for the physical protection system that have to be provided in the current period and short term.

Today, there is no way to effectively fight with prepared violators to achieve their goals using any of the known singlesensor systems.

It is concluded that there is a need to develop a multi-sensor system, minimum equipment of which should include interconnected seismic and vibro-acoustic subsystems. Combination of vibro-acoustic and seismoanalytical subsystems allows compensating the most significant drawbacks of each of them.

\section{Ключевые слова:}

магистральные трубопроводы, террористические угрозы, несанкционированные врезки, система физической защиты, надежность обнаружения, мультисенсорные системы, виброакустические колебания, обнаружение утечек, охранная зона, сейсмические колебания, затраты на защиту объекта, проблема предотвращения хищений нефти, вероятности ошибок 1-го и 2-го рода, экономический ущерб, затраты на защиту объекта.

\begin{abstract}
Цель статьи - обосновать подход к определению требуемого значения вероятности обнаружения несанкционированных попыток контактировать с оболочкой трубы для поддержания минимального уровня потерь на охрану трубопровода, оценить тенденцию ее изменения в ближайшей перспективе и на основе этой информации предложить структуру системы физической защить магистральных трубопроводов для нейтрализации террористических атак. Приведены результаты исследований виброакустических колебаний в оболочке трубы магистрального продуктопровода в процессе его эксплуатации. Дано объяснение механизмам изменения параметров виброакустического импульса, возбужденного в локальной точке трубопровода, при его распространении по трубопроводу. Рассмотрены результаты исследований по решению задачи обнаружения и предотвращения возникновений чрезвычайной ситуаций в охранной зоне по сейсмическим колебаниям. Сделан вывод о возможности обнаружения предвестников чрезвычайных ситуаций по виброакустическим и сейсмическим колебаниям оболочки трубы. Продемонстрирована эффективность предложенного подхода по определению требований к системам защиты объектов от террористических угроз. Выбор региона определился наличием опубликованных данных, охватывающих сравнительно протяженный период, необходимых для постановки вычислительного эксперимента. Представляет интерес получать прогнозные оценки в этом сегменте экономики для страны в целом.

Наличие такой информации позволит сформировать политику по обнаружению террористических атак и определиться с требованиями к системе физической защиты, которые необходимо обеспечить в текущий период и в ближайшей перспективе.

На сегодняшний день не просматривается возможность эффективного противодействия подготовленным нарушителям по достижению поставленных ими целей с помощью любых из известных односенсорных систем.

Сделан вывод о необходимости разработки мультисенсорной системы, минимальная комплектация которой должна включать взаимосвязанные сейсмическую и виброакустическую подсистемы. Комбинация виброакустической и
\end{abstract} сейсмоаналитической подсистем позволяет компенсировать наиболее значимые недостатки каждой из них.

Vladimir A. Komarov (Author ID in Scopus: 57197211324) - PhD student at the Department of Information Security (tel.: +007913 631 00 57, e-mail:reallkom@gmail.com). Zinaida V. Semenova - Doctor of Pedagogy, Professor, Head of the Department of Information Security (tel.: +007 913 615 89 758, e-mail: zvs111@gmail.com). Evgeniy M. Mikhaylov - PhD in Engineering, Associate Professor at the Department of Information Security (tel.: +007 913 615 17 50, e-mail: emm100@mail.ru). Aleksey A. Nigrey (Author ID in Scopus: 57200720879) - PhD student at the Department of Information Security (tel.: +007 913 638 60 02, e-mail: nigrey.n@mail.ru). The contact person for correspondence. Dmitriy A. Bronnikov (Author ID in Scopus: 57200729064) - PhD student at the Department of Information Security (tel.: +007 929 365 85 37, e-mail: dmi-bronnikov@yandex.ru).

Комаров Владимир Александрович - аспирант кафедры информационной безопасности (тел.: +007 913 631 00 57, e-mail: reallkom@gmail.com). Семенова Зинаида Васильевна - доктор педагогических наук, профессор, заведующая кафедрой информационной безопасности (тел.: +007 91361589758 , e-mail: zvs111@gmail.com).

Михайлов Евгений Михайлович - кандидат технических наук, доцент кафедры информационной безопасности (тел.: +007913 615 1750 , e-mail: emm100@mail.ru). Нигрей Алексей Андреевич - аспирант кафедры информационной безопасности (тел.: +007 91363860 02, e-mail: nigrey.n@)mail.ru). Контактное лицо для переписки. Бронников Дмитрий Алексеевич - аспирант кафедры информационной безопасности (тел.: +007 929 365 85 37, e-mail: dmi-bronnikov@yandex.ru) 


\section{Introduction}

Detection of unauthorized tie-ins and prevention oil theft from pipelines are the most relevant and complex problems in operation of main pipelines [1]. Over the past 5 years in the territory of the Russian Federation almost 5.000 unauthorized tie-ins have been identified. That represents $70 \%$ of all crimes related to the theft of oil and its products. One in four of these tie-ins was found in the territory of Samara region [2]. According to a president of Transneft, there were in 2014 in the regions of the Russian Federation 320 criminal incidents identified in the main pipelines, 385 tie-ins in 2015 and 238 tie-ins for 10 months in 2016 [3].

Criminal interventions in the operation of the main pipelines pose the greatest threat to the environment, as they cause spills of oil and its products, pollution of soil, rivers and reservoirs.

The problem of criminal tie-ins and theft of oil from the main oil pipelines is viewed by experts as a serious multifactor threat to Russia's national security. According to the data obtained by the author [4], the share of all accidents for this reason is $69 \%$ of all accidents.

Analysis of annual reports on the activities of the Federal Service for Environmental, Technological and Nuclear Supervision for 2010-2016 [5] indicates that the number of accidents on the main pipelines are decreasing over time (Fig. 1).

According to official data of Rostekhnadzor, annual economic damage to enterprises from accidents at the main pipeline transport facilities is estimated as hundreds of millions of rubles [5] (Fig. 2).

The authors of [6] carried out an analysis of publications on ensuring the safety of pipeline transport and detection of unauthorized work in the

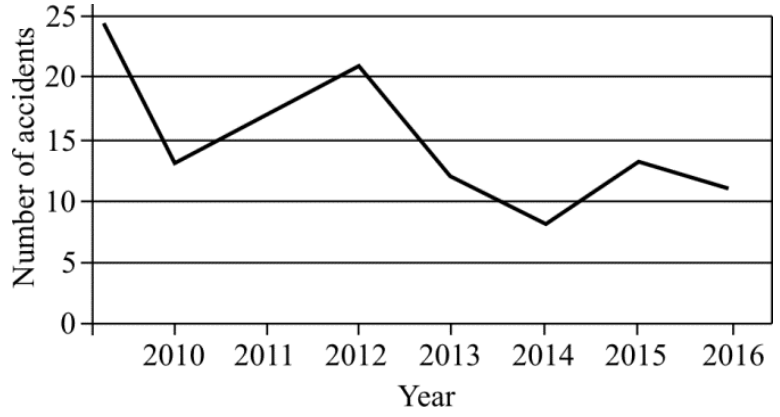

Fig. 1. Dynamics of accidents on the main pipelines of Russia from 2010 to 2016

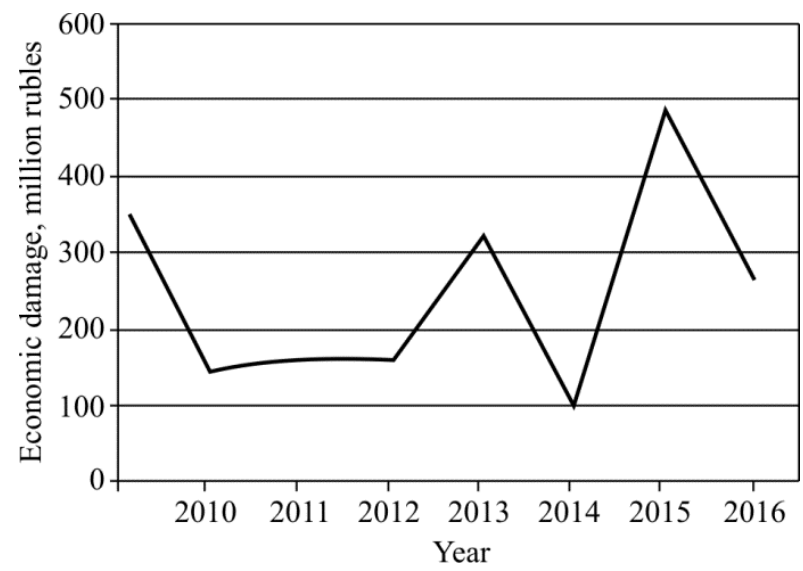

Fig. 2. Economic damage for enterprises from accidents on the main pipelines from 2007 to 2016

guard zone of the monitoring facility. The analysis showed that the research are mainly focused on creating a system of physical protection of the main pipelines that implements the principle "not to miss the contact of the attacker with the pipe shell".

In the paper [6] the authors indicate that over the past few years a significant number of publications on this subject have been presented in international databases. So, there are more than 80 publications in the Web of Science database and 60 publications in Scopus. The analysis of RISC database publications over the last 5 years (2012-2016) indicates that there is an interest renewed among the scientists in the problem of ensuring the safety of pipeline transport and the detection of unauthorized tie-ins over 90 (Fig. 3). 


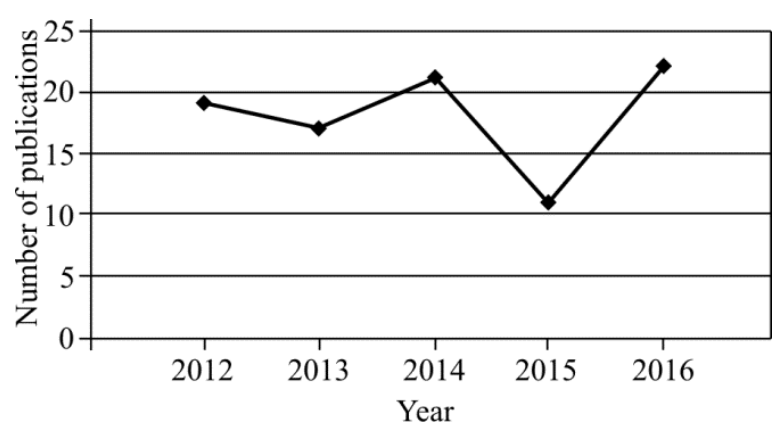

Fig. 3. Dynamics of the publication activity in the RISC database on the problem of ensuring the safety of pipeline transport and detection of unauthorized work in the guard zone of the monitoring facility from 2012 to 2016

Therefore, at the present stage of development of pipeline transport of oil and oil products, the issue of ensuring reliable and fail-safe operation of main pipelines.

There is a number of studies aimed to solve the problem of detection and prevention the emergencies in the protection zone by seismic fluctuations [7-9]. Improving the parameters of video analytics system to detect suspicious activity of subjects in the zone of control is declared by the patent [10]. It is proposed to carry out exploration of small leaks of the pumped product using thermal imaging systems installed on air vehicles [11]. The possibility of using thermal imaging systems for detecting product leaks and camouflaged excavation sites was considered in $[12,13]$. The transfer characteristic of the transmission path of vibro-acoustic signals formed in the pipeline envelope is determined by a number of factors, including the state of soil adjacent to it. This circumstance is used to detect product leaks and excavations in the area of the monitored facility [14-17]. In some cases, video analytics systems are used to allow one to trace the behavior of the subject(s) in the guard zone of the monitoring object $[18,19]$.

The greatest interest is shown in the investigation of a fiber-optic cable for the detection of unauthorized work in the pipeline security zone $[20,21]$. Seismic vibrations cause deformation of the cable, their intensity in any place is determined by the optical signals reflected from the heterogeneities. Suppression of accompanying noise is considered to be the the main problem of fiber-optic technology in the current period. Nonstationary fluctuations in seismic fields reduce the reliability of detection of signals from objects. The problem of obtaining reasonable estimates for probabilities of identifying event types in the analysis of processes recorded from optical fiber processes is discussed in [22]. However, it is truly noted in [23] that there is no reliable data on the satisfactory operation of such systems on extended objects (over $10 \mathrm{~km}$ ). The paper presents the results of tests of the domestic system Danube. Its ability to detect the movement of heavy equipment and develop of soil by a mechanical method in the zone of sensitivity of the fiber-optic cable is proved. The detection zone of heavy equipment was $100-150 \mathrm{~m}$ and $50-100 \mathrm{~m}$ for mechanical soil development. The sensitivity depends on a number of factors: depth of the cable laying, type of the cable, type of soil and its condition (dry, wet, frozen), type of event, distance to the reflectometer. Since surface acoustic waves reach the cable, the optimum depth of cable laying is 30 $40 \mathrm{~cm}$.

There is a conclusion made in [24] about the need for R\&D, as well as the development of data processing techniques to further improve the technology. The feature of the study is that there is no description in required details of conditions for carrying out the experiments and estimates obtained for the probabilities of errors of the first and second kind. There is also no information on the operability of the systems under investigation in the presence of artificially created interference by the attackers. There is no reasonable data on 
reliability of intrusion detection of persons in the pipeline security zone and classifications of their actions. Directive assessments like “... the minimum time to false alarm ... should not be less than 170 hours ( 1 week), good immunity is characterized by $\mathrm{T}_{\text {f.a }} \geq 720 \mathrm{~h}$ (1 month)" [25] do not have a serious evidence base $\left(T_{\text {f.a }}-\right.$ duration of the interval of $1^{\text {st }}$ false alarm).

\section{A problem statement}

In accordance with system laws, the process of improving the technology for solving specific problems is first characterized by the fastest rate of increase in its parameters. Then there is a slowdown in growth and sharp increase in costs to ensure an insignificant increase in these parameters. There is an evolutionary law of technology development, described by an S-shaped curve.

The possibilities of improving the methods of detecting and recognizing images obey the same pattern. After the attainment of certain values of the probabilities of errors of the $1^{\text {st }}$ and $2^{\text {nd }}$ kind, their further insignificant decrease is associated with such a massive increase in the necessary resources. That looses its meaning in realization of the intention. It is necessary to use a new method or combination of the old and new ones.

Fig. 4 shows the graphs reflecting the loss of the owner of the object during its operation, depending on the probability of detecting terrorist attacks $P_{a}$ [26]. The less money is invested in ensuring the security of the infrastructure created, the greater losses that can be expected when it is used. The minimum point of total loss determines the required probability of detecting attacks.

Improving the one-sensor systems to increase the probability of $R_{\mathrm{a}}$ at the last stage of the " $S$-shaped" development is associated with high costs. There are limits to improvement: the opposing side invents new methods of attacking.

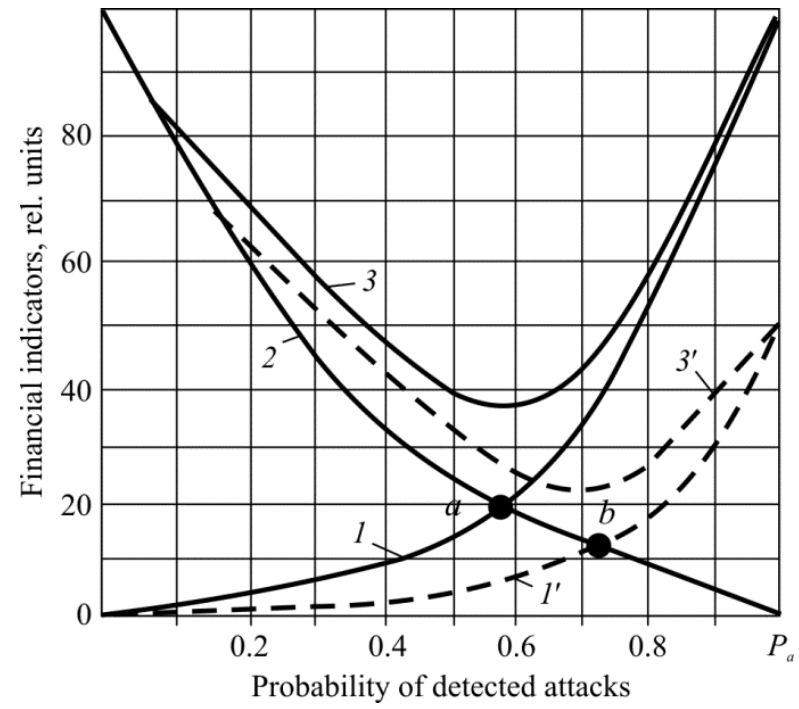

Fig. 4. Financial indicators of the parties' confrontation depending on the likelihood of detecting attacks $P_{a}$ : $1\left(1^{\prime}\right)$ - protection costs when using single-sensor (1) and multi-sensor ( $\left(1^{\prime}\right)$ systems; 2 - damage from missed attacks; $3\left(3^{\prime}\right)$ - total losses of the owner of the object when using the single-sensor (3) and multisensor (3') systems with points $a, b$

This circumstance stimulates the development of multisensor systems (curves $l^{\prime}$ and $3^{\prime}$ in Fig. 4 reflect their ability to reduce costs).

The owner of the object knows the costs of its protection and losses from missed attacks. It is possible to estimate on them the direction of improvement of the counteraction system for ensuring the optimal value $P_{a}$.

Position and shape of the curves given in Fig. 4 are limitation of the approach described. The curves reflect the expenditure items depend on many factors, the dynamics of their change exceeds the real possibilities for modernizing the systems to counter threats.

It is necessary to have predictive information about the intensity of terrorist activities and conditions for conducting it in the short term, in order to take into account these data when developing technologies for the purpose in question. The approach for obtaining such the information is developed in the paper. 


\section{Theoretical analysis}

A generalized model that allows solving the posed problem can be represented as

$$
\begin{gathered}
\frac{d N_{1}}{d t}=\left[f_{1}\left(\mathrm{GDP}, \frac{\mathrm{I}}{\mathrm{C}}\right)-f_{2}\left(\frac{\mathrm{MH}_{90}}{\mathrm{MH}_{t}}\right)-\frac{\alpha_{1} \beta_{1}}{\alpha_{2} \beta_{2}} \cdot y N_{2}\right] \cdot N_{1}(t) ; \\
\frac{d N_{2}}{d t}=\left[f_{3}\left(\frac{\mathrm{PC}}{\mathrm{L}}\right)-f_{4}\left(\frac{\mathrm{S}}{\mathrm{I}}\right)+\frac{\alpha_{2} \beta_{2}}{\alpha_{1} \beta_{1}} \cdot y N_{1}\right] \cdot N_{2}(t),
\end{gathered}
$$

where $N_{1}$ - the number of attacks on the protected object; GDP - the gross domestic product per capita in the past year; I/S - the ratio of average income from the transaction to the cost of its conduction; $\mathrm{MH}_{90} / \mathrm{MH}_{t}$ - the ratio of the moral health of the population of the country (region), respectively, in the $90^{\text {th }}$ and current years; $\alpha_{1}, \beta_{1}-$ levels of qualification and technical equipment of the attacking party; $\alpha_{2}, \beta_{2}$ - levels of qualifications and technical equipment of defenders; $\mathrm{S}-$ salaries of defenders; $\gamma-$ the coefficient of interaction of defenders and attackers, which are inversely related to the size/extent/area of the protected object; $N_{2}$ - the number of defenders of the object; $\mathrm{C}$ - costs for object protection, $\mathrm{L}$ - total losses from attacks on the protected object.

The GDP characterizes the poverty of society, the function $f_{1}(\mathrm{GDP}=$ const, $\mathrm{D} / \mathrm{R})$ characterizes the proportion of the population willing to commit an offense depending on the expected income and having sufficient knowledge to commit a crime in the sphere of activity in question. Obviously, in case of $(\mathrm{I} / \mathrm{S}) \leq 1$ function value $f_{1}(\mathrm{GDP}=$ const, $\mathrm{I} / \mathrm{S}$ ) $=1$ (there is no sense in carrying out the operation without getting any profit; the factor of "revenge" is not taken into account). The curve $f_{1}(\mathrm{GDP}=$ const, $\mathrm{I} / \mathrm{S})$ has a saturation region, when the resource of members capable of committing an offense of a given kind is exhausted. For communities characterized by a different ratio of limiting factors, the shape of the curve is preserved but its coefficients change:

$$
\begin{gathered}
f_{1}(\mathrm{GDP}=\text { const, } \mathrm{I} / \mathrm{S})= \\
=a_{1} /\left(1+b_{1} \exp \left(-c_{1} \mathrm{I} / \mathrm{S}\right)\right),
\end{gathered}
$$

where $a_{1}$ - the coefficient that determines the part of society potentially ready to move to the camp of offenders from selfish interests. Coefficients $a_{1}, b_{1}$, $c_{1}$ are determined by expert technologies taking into account the GDP received in the previous year.

The function $f_{2}\left(\mathrm{MH}_{90} / \mathrm{MH}_{t}\right)=\left(\mathrm{MH}_{90} / \mathrm{MH}_{t}\right)$ $f_{1}(\mathrm{I} / \mathrm{S})$ characterizes the lawfulness of the population, its cultural level and legislative framework for combating the relevant type of crime. $\mathrm{MH}_{t}$ acts as an integrated indicator, estimated from the state statistics (on indicators that characterize the social tension in society). Functions $f_{3}, f_{4}$ are special cases of logistic curves.

Obviously, the higher the $N_{2}$ the higher the cost of protecting the object of ST. Total losses from attacks L increase with the number of attacks, i.e. with growth of $N_{1}$. One of the possible variants of the function $f_{3}$ (ST, $\mathrm{P}, N_{1}, N_{2}$ ), taking into account its logistic characteris

$$
f_{3}=\frac{a_{3} \exp \left(\frac{\mathrm{L} N_{1}}{\mathrm{PC} \cdot N_{2}} b_{3}-c_{3}\right)}{\left(1+\exp \left(\frac{\mathrm{L} N_{1}}{\mathrm{PC} \cdot N_{2}} b_{3}-c_{3}\right)\right)},
$$

where $a_{3}, b_{3}, c_{3}$ - curve shape factors.

Assessment of the state of protection and its difference from the optimal (equal protection costs and losses from attacks on the object) is made using the value of registered $d N_{1}(t) / d t$, current expenditures for protection of the facility and losses from attacks on it, $\mathrm{D} / \mathrm{P}$ value determined by the survey of the population of the adjacent territories and the tracked ratio $\mathrm{MH}_{90} / \mathrm{MH}_{t}$. This assessment determines the requirements for 
probability of detection of attacks and false alarms, which should be provided by the security service of the facility.

A particular case arising from the model (1) and reflecting the interaction in the "terroristdefense system of the main product pipelinepolice" system can be represented as a system of four equations [27]:

$$
\begin{gathered}
\frac{d N_{\mathrm{L}}}{d t}=r_{\mathrm{L} 0}\left(1-\frac{N_{\mathrm{L}}}{N_{\mathrm{L} 0} N_{\mathrm{Lmax}}}\right) N_{\mathrm{L}}- \\
-\alpha_{\mathrm{L}} P_{a} m_{\mathrm{L}} P_{\mathrm{M}} N_{\mathrm{L}} N_{\mathrm{M}}+r_{\mathrm{L} 2} ; \\
\frac{d N_{\mathrm{B}}}{d t}=\alpha_{\mathrm{L}}\left(\frac{N_{\mathrm{L}}}{g_{\mathrm{L}}}-N_{\mathrm{L}}\right)-\frac{N_{\mathrm{L}}}{g_{\mathrm{L}}} P_{a} \alpha_{\mathrm{L}} ; \\
\frac{d N}{d t}=r_{s 0}\left(\frac{D_{\mathrm{B}}\left(-t_{s}\right)}{b_{\mathrm{B}} D_{0}}\right)^{k_{s 1}}-r_{s 1}\left(\frac{D_{s}}{b_{s} D_{\mathrm{B}}\left(-t_{s}\right)}\right)^{k_{s 2}} ; \\
\frac{d N_{\mathrm{M}}}{d t}=\frac{N_{\mathrm{L}}\left(-t_{\mathrm{M}}\right)}{g_{\mathrm{L}}} P_{\mathrm{B}}\left(-t_{\mathrm{M}}\right) \alpha_{\mathrm{L}} r_{\mathrm{M} 0}- \\
-r_{\mathrm{M} 1} N_{\mathrm{M}}+r_{\mathrm{M} 2} N_{\mathrm{L}},
\end{gathered}
$$

where $N_{\mathrm{L}}(t)$ - the number of terrorist attacks at time $t ; N_{\mathrm{B}}-$ the number of attacks on the object; $N_{\mathrm{p}}$ - the number of pipeline protection elements; $N_{\mathrm{M}}$ - the number of police officers, involved in the investigation of criminal activities on the main pipelines; $r_{\mathrm{L} 0}-$ expansion coefficient of information between members of society ("viral" factor) [28]; $\quad N_{\mathrm{L} m}-$ the capacity of the environment in which the "idea of product theft" will spread into [29]; $\alpha_{L}-$ the average number of terrorist group yields per object of attack per unit time; $P_{a}-$ likelihood of attack detection; $m_{\mathrm{L}}-$ probability of detaining terrorists; $P_{\mathrm{M}}$ - probability of conviction of detained terrorists; $r_{\mathrm{L} 2}$ - coefficient of increase in the number of adherents of the idea of product theft; $g_{\mathrm{L}}-$ average size of a group of terrorists; $r_{s 0}$, $r_{s 1}$ - coefficients of increase and decrease in costs for the protection of the object; $k_{s 0}, k_{s 1}$ - the protection strategy factors that determine the limiting values of the missed attack probability and false decisions of the object protection system used; $D_{\mathrm{B}}-$ casualty losses $t_{s} ; D_{s}-$ object protection costs; $b_{\mathrm{B}}$ - loss of the share of income from the operation of the facility as a result of the attack; $b_{s}-$ the ratio of losses from attacks to costs of object protection; $t_{\mathrm{M}}$ - the delay in responding police structures to a registered attack; $r_{\mathrm{M} 0}, r_{\mathrm{M} 1}$ - respectively, the growth rate and reduction in the number of police officers involved in investigating the facts of attacks on the protected object; $r_{\mathrm{M} 2}$ - the coefficient of growth of police officers in case of change in theft activities.

\section{Computational experiment}

The computational experiment was carried out on the example of Samara region in connection with availability of published data covering a relatively long period of time. There are on the territory of Samara region 24 main oil pipelines and 4 oil pipelines with a length of about 4 thousand $\mathrm{km}$, operated by organizations of the system "Transneft" (Privolzhsnefteprovod - 1.837 thousand km, Northwest MN OJSC $965 \mathrm{~km}$, Druzhba oil pipeline - $538 \mathrm{~km}$, 2 subsidiaries of Transnefteproduct - South-West Transnefteprodukt - $366 \mathrm{~km}$ and Uraltransnefteprodukt - $228 \mathrm{~km}$ ). On average, over 310 million tons of oil and oil products are pumped through the territory of Samara region over the year.

Theft of oil in Samara region took a significant scale. According to the pipeline security officer, in the early 2000 s there was no empty space on the map of Samara region pipelines, where the red dots denoted the tie-ins to the pipe. About 1 million tons of oil was stolen in one year only. There 44 tie-ins were recorded in 2010. Then, after Transneft installed control 
systems, the scale of oil theft was reduced [30], and in 201123 tie-ins were recorded. By 2012, the number of reports in the media about tie-ins to oil pipelines was increased sharply. The largest number of reports occurred in the Irkutsk, Leningrad, Samara regions.

In 2012 Samara region became the allRussian leader in the number of criminal tie-ins to main pipelines. In 2012, according to Transneft, 34 criminal encroachments on trunk pipelines were recorded in Samara region. In all regions at that time the number of frames was reduced. In Samara region it grew by $67.4 \%$. Since the beginning of 2013 in the Samara region, 55 illegal taps in oil pipelines and 26 in main pipelines have been identified. Following the results of 2013, the Samara region took the first place in Russia in terms of theft of oil from the main pipelines.
From 2003 to 2013 almost a quarter of criminal tie-ins to the pipeline system were detected in the region from the total number of frames detected in Russia, in particular 1651 unauthorized tie-ins. But in 2014 the number of unauthorized cuts in main oil pipelines dropped to 17. According to [31], there were 32 unauthorized taps revealed in the main pipelines in 2015 and 24 cases in pipelines by October 2016.

The adequacy of the model (2) is verified by comparing the simulation results of the "mortal terrorism" process in Samara region with the real data presented in the published materials for the period from 2010 to 2016 .

Long-term projections based on the model in question predict a new cycle of significant growth in terrorist attacks on main pipelines, with a subsequent decline by the end of the third decade (Fig. 5).

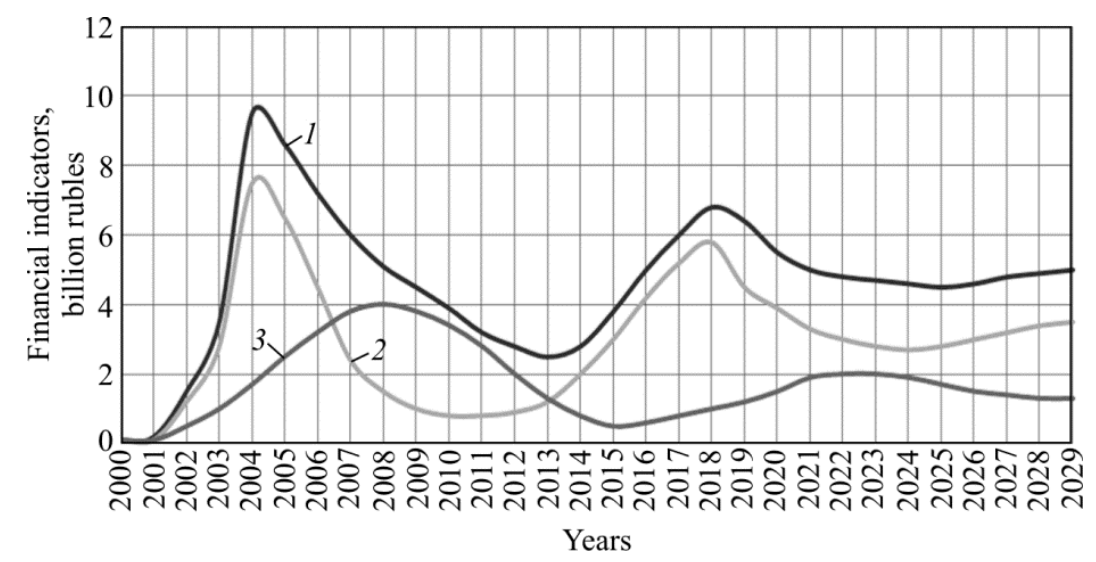

Fig. 5. Forecast of financial indicators of the parties' confrontation until 2029, while maintaining the current level of probability of detection of attacks by defense systems: 1 - annual total costs, billion rubles; 2 - annual damage from frames, billion rubles; 3 - annual protection costs, billion rubles

Information about the actual costs of protection and the size of losses from the frames is of a closed nature. Therefore, the data given in Fig. 5 reflect trends in the costs of protection and damage from product theft with the figures taken at the initial time (2000). Other indicators of the model correspond to those established for the Samara region at the same time.

\section{Results and discussions. Conclusions}

The model (2) allows to estimate the required probability of detection of attacks $P_{a}$. The results 
of modeling one of the scenarios for countering terrorist attacks (see Fig. 5) allow to conclude that the most favorable moment in 2013 was observed in organizing the protection of pipeline transport. From this point of view, it would be necessary to increase the costs of protecting the facilities in order to prevent the growth of total costs in the short term.

The effectiveness of the approach proposed to determine the requirements for systems to protect objects from terrorist threats is demonstrated in the example of the Samara region. The region was chosen by the availability of published data covering a relatively long period of time necessary for setting up a computational experiment. It is of interest to receive projections in this segment of the economy for the country as a whole.

The availability of such information will make it possible to formulate a policy for detecting terrorist attacks and determine the requirements for the physical protection system that must be provided in the current period and in the short term.

Today, there is no way to effectively counter prepared violators to achieve their goals using any of the known single-sensor systems. It is necessary to determine the composition of multisensory systems. The combination of vibroacoustic and seismo-analytical subsystems allows to compensate the most significant drawbacks of each of them.

\section{References}

1. Tsviak A.V. Ekologicheskie posledstviia nesanktsionirovannykh vrezok $\mathrm{v}$ nefteprovody $\mathrm{i}$ metody bor'by $\mathrm{s}$ nimi [Environmental impact unapproved inserts in the pipeline and methods of combating them]. Vestnik Orenburgskogo gosudarstvennogo universiteta, 2015, no.10 (185), pp.445-447.

2. V Samarskoi oblasti neftevrezchiki otkachali $\mathrm{v}$ odnom meste pochti 7000 tonn "chernogo zolota" [In the Samara region, oil cutters pumped out almost 7,000 tons of "black gold" in one place], available at: http://www.trkterra.ru/tag/ neftevrezka (accessd 08 August 2017).

3. Ob itogakh soveshchaniia PAO "Transneft", predstavitelei rukovodstva pravookhranitel'nykh, kontroliruiushchikh i nadzornykh organov g. Sankt-Peterburga i Leningradskoi oblasti 22 noiabria 2016 goda [On results of the meeting of Transneft PJSC, representatives of the leadership of law enforcement, supervisory and supervisory bodies of St. Petersburg and the Leningrad Region on November 22, 2016], available at: http://www.lenoblinform.ru/news/ Transneft-221116.html (accessd 08 August 2017).

4. Aleksenko K.S., Fedotova N.S. Monitoring i otsenka utechek na nefteprovodakh [Monitoring and evaluation of oil pipeline leaks]. Nauchnoe soobshchestvo studentov XXI stoletiia. Tekhnicheskie nauki, available at: https://sibac.info/archive/technic/11(47).pdf (accessed 12 May 2017).

5. Materialy ezhegodnykh otchetov o deiatel'nosti Federal'noi sluzhby po ekologicheskomu, tekhnologicheskomu i atomnomu nadzoru (2007-2016 gg.) [Materials of annual reports on activities of the Federal Environmental, Industrial and Nuclear Supervision Service of Russia (2007-2016)], available at: http://www.gosnadzor.ru/public/annual_reports (accessed 12 May 2017).

6. Bronnikov D.A., Komarov V.A., Nigrei A.A. Obespechenie bezopasnosti magistral'nykh produktoprovodov ot terroristicheskikh ugroz: vzgliad na reshenie problemy [Ensuring the safety 
of major pipelines against terrorist threats: a look at the solution of the problem]. Novaia nauka: strategii $i$ vektory razvitiia. Sbornik statei po itogam Mezhdunarodnoi nauchno-prakticheskoi konferentsii. Sterlitamak, AMI, 2016, part 2, pp.155-159.

7. Ron Zehavi, Yehud. System and method for detecting, locating and discerning an approach towards a linear installation. Patent 0251343 A1 USA, MPK G01V 1/00, no. $11 / 107,647$

8. Virginia Ann Zingelewicz, Helena Goldfarb, Corey Nicholas Bufi, Steven Hector Azzaro, Jeffrey Scott Thetford. System and method for securing an infrastructure. Patent 0096896 A1 USA, MPK G08B 19/00 (2006.01), no. $11 / 260,897$.

9. Corey Nicholas Bufi, Sahika Genc. System and method for generation a threat alert. Patent 0245026 A1 USA, MPK H04B 1/10 (2006.01), no. $12 / 054,510$.

10. Khomenko V.I., Vinnichenko S.A., Molchanov V.V. Sistema videonabliudeniia za opasnym uchastkom magistral'nogo gazoprovoda [System of video surveillance over a dangerous section of the major gas pipeline]. Patent 2334163 Russian Federation, MPK F17D5/00, F16L55/26, G01M3/00; no. 2007105552/06.

11. Akhmetov D.K., Kushnarev V.I., Solomonov Iu.S., Zhirukhin Iu.N., Frantsuzov V.A. Sposob obnaruzheniia mesta utechki ili nesanktsionirovannogo otbora nefti na lineinoi chasti magistral'nogo nefteprovoda [The method for locating a leak or unauthorized oil withdrawal on the linear part of the main oil pipeline]. Patent 2273888 Russian Federation, MPK7 G 08 B 25/10 \%F 17 D 5/02; no. 2005131056/11.

12. Geoplace - GEOEurope - Aerial imaging applications in pipeline industry, available at: www.geoplace.com/ge/20016070160701 pip.asp (accessed 12 May 2017).

13. Epifantsev B.N. Distantsionnaia diagnostika podzemnykh truboprovodov po teplovomu izlucheniiu [Remote diagnostics of underground pipelines for thermal radiation]. Defektoskopiia, 2014, no.3, pp.28-39.

14. Ozevin Didem, Harding James. Novel leak localization in pressurized pipeline networks using acoustic emission and geometric connectivity. International Journal of Pressure Vessels and Piping, 2012, vol.92, pp.63-69. DOI: 10.1016/2012.01.001.

15. Epifantsev B.N. An acoustic method for diagnostics of the state of underground pipelines: new possibilities. Russian Journal of Nondestructive Testing, 2014, vol.50, no.5, pp.254-257. DOI: 10.1134/S1061830914050039

16. Epifantsev B.N., Pyatkov A.A., Fedotov A.A. Evaluation of the sensitivity of a vibroacoustic detection system for local disturbances of trunk pipeline environmental parameters. Russian Journal of Nondestructive Testing, 2015, vol.51, no.2, pp.70-78. DOI: 10.1134/S1061830915020035.

17. Komarov V.A., Epifantsev B.N. Vibroakusticheskii kontrol' sostoianiia magistral'nykh produktoprovodov: adaptatsiia $\mathrm{k}$ izmeneniiam parametrov okruzhaiushchei sredy [Vibro-acoustic monitoring of the state of the major pipelines: adaptation to changes in environmental parameters]. Kompleksnoe obespechenie informatsionnoi bezopasnosti avtomatizirovannykh sistem. Annotirovannyi sbornik vypusknykh kvalifikatsionnykh rabot FGBOU VO "SibADI". Omsk, pp.38-45.

18. Dollar P. et al. Pedestrian detection: an evaluation of the state of the art. IEEE Trans. on Pattern Analysis and Machine 
Intelligence, 2012, vol.34, no.4, pp.743-761. DOI: 10.1109/TPAMI.2011.155

19. Epifantsev B.N., Piatkov, A.A., Kopeikin, S.A. Mul'tisensornye sistemy monitoringa territorii ogranichennogo dostupa: vozmozhnost' videoanaliticheskogo kanala obnaruzheniia vtorzhenii [Multi-sensor systems for monitoring access to restricted areas: capabilities of the intrusion detection video analytical channel]. Komp'iuternaia optika, 2016, no.1, pp.121-129.

20. Klar A., Linker R. Fiber optic sensing optical fibers detect tunnel-digging. Laser Focus World: Lasers, Photonics, Optics News \& Technology Advances, 2009, available at: http://www.laserfocusworld.com/articles/print/volu me-45/issue-4/world-news/fiber-optic-sensing-optical-fibers-detect-tunnel-digging.html (accessed 12 May 2017).

21. Duckworth G., Ku E. OptaSense (R) distributed acoustic and Seismic sensing using COTS fiber optic cables for Infrastructure Protection and Counter Terrorism. Sensors and command, control, communications and intelligence (c3i) Technologies for homeland security and homeland deference XII, 2013, vol.8711, no.UNSP87110G. DOI: 10.1117/12.2017712.

22. Wang J. FBG intrusion recognition algorithm based on SVM. Advanced Materials Research, 2012, vol.591-593, pp.1422-1427. DOI: 10.4028/www.scientific.net/AMR.591-593.1422

23. Nesterov E.T., Marchenko K.V., Treshchikov V.N., Leonov A.V. Volokonnoopticheskaia sistema monitoringa protiazhennykh ob"ektov (nefteprovodov) na osnove kogerentnogo reflektometra [Fiber-optic monitoring system for long objects (oil pipelines) based on a coherent reflectometer]. T-Comm, 2014, no.1, pp.25-28.

24. Shekhovtsev A.V., Mansurov M.N., Golubin S.I. Eksperimental'nye issledovaniia volokonno-opticheskogo metoda obnaruzheniia utechek iz nefteprovodov [Experimental studies of the fiber-optic method for detecting leaks from oil pipelines]. Truboprovodnyi transport: teoriia $i$ praktika, 2015, no.6(52), pp.0-35.

25. Zvezhinskii S.S. Problema vybora perimetrovykh sredstv obnaruzheniia [The problem of choosing perimeter detection tools]. Spetsial'naia tekhnika, 2002, no.4, pp.36-41.

26. Epifantsev B.N., Kopeikin S.A. O veroiatnosti obnaruzheniia terroristicheskikh ugroz sistemami fizicheskoi zashchity magistral'nykh truboprovodov [On the probability of detecting terrorist threats by physical protection systems of major pipelines]. Dinamika sistem, mekhanizmov $i$ mashin, 2016, vol.1, no. 2, pp.246-252.

27. Epifantsev B.N., Piatkov A.A. Preduprezhdenie chrezvychainykh situatsii na magistral'nykh produktoprovodakh. Chast' 1. Obnaruzhenie nesanktsionirovannykh vtorzhenii v okhrannuiu khonu produktoprovoda [Prevention of emergency situations on the major pipelines. Part 1. Detection of unauthorized intrusions into the security zone of the pipeline]. Omsk, 2013, 122 p.

28. Bass F.M. A new product growth for model consumer durables. Management Science, 1969, pp.215-227. DOI: 10.1287/mnsc.15.5.215

29. Becker G.S. Crime and punishment: an economic approach. The Journal of Political Economy, 1968, vol.76, no.2, pp.169-217. DOI: $10.1086 / 259394$

30. Korytina E. Desiat' sposobov ukrast' neft' $v$ Rossii [Ten ways to steal oil in Russia]. RBK daily, 18.07.2011, available at: http://www.rbcdaily.ru/2011/07/18/tek/562959980 660282 (accessed 12 May 2017).

31. Informatsionno-analiticheskie materialy dlia zasedaniia komissii po protivodeistviiu nezakonnomu oborotu promyshlennoi produktsii $\mathrm{v}$ 
Samarskoi oblasti, dekabr' 2016 g. [Information and analytical materials for the meeting of the commission for combating illegal trafficking of industrial products in the Samara region, December 2016], available at: http://samgd.ru/analytics/ notes/183926. (accessed 12 May 2017).

\section{Библиографический список}

1. Цвяк А.В. Экологические последствия несанкционированных врезок в нефтепроводы и методы борьбы с ними // Вестник Оренбургского государственного университета. - 2015. № 10 (185). - С. 445-447.

2. В Самарской области нефтеврезчики откачали в одном месте почти 7000 тонн «черного золота» [Электронный ресурс]. URL: http://www.trkterra.ru/tag/neftevrezka (дата обращения: 08.08.2018).

3. Об итогах совещания ПАО «Транснефть», представителей руководства правоохранительных, контролирующих и надзорных органов г. Санкт-Петербурга и Ленинградской области 22 ноября 2016 года [Электронный pecypc]. - URL: (http://www.lenoblinform.ru/ news/Transneft-221116.html (дата обращения: 08.08.2018).

4. Алексенко К.С., Федотова Н.С. Мониторинг и оценка утечек на нефтепроводах [Электронный ресурс] // Научное сообщество студентов XXI столетия. Технические науки: сб. ст. по мат. XLVIII междунар. студ. науч.-практ. конф. - Новосибирск, 2016. - № 11(47). - URL: https://sibac.info/archive/ technic/11(47).pdf (дата обращения: 12.05.2017).

5. Материалы ежегодных отчетов о деятельности Федеральной службы по экологическому, технологическому и атомному надзору (2007-2016 гг.) [Электронный ресурс]. URL: $\quad \mathrm{http}: / /$ www.gosnadzor.ru/public/annual_ reports (дата обращения: 12.05.2017).

6. Бронников Д.А., Комаров В.А., Нигрей А.А. Обеспечение безопасности магистральных продуктопроводов от террористических угроз: взгляд на решение проблемы // Новая наука: стратегии и векторы развития: сб. статей по итогам междунар. науч.-практ. конф.: в 3 ч. Ч. 2. - Стерлитамак: АМИ, 2016. - С. 155-159.

7. System and method for detecting, locating and discerning an approach towards a linear installation: пат. 0251343 A1 США, МПК G01V 1/00 / Ron Zehavi, Yehud. - № 11/107,647; заявл. 14.04.2005; опубл. 10.11.2005; НПК 702/18.

8. System and method for securing an infrastructure: пат. 0096896 А1 США, МПК G08B 19/00 (2006.01) / Virginia Ann Zingelewicz, Helena Goldfarb, Corey Nicholas Bufi, Steven Hector Azzaro, Jeffrey Scott Thetford. - № 11/260,897; заявл. 28.20.2005; опубл. 03.05.2007; НПК 340/522.

9. System and method for generation a threat alert: пат. 0245026 А1 США, МПК Н04В 1/10 (2006.01) / Corey Nicholas Bufi, Sahika Genc. № $12 / 054,510 ;$ заявл. 25.3.2008; опубл. 01.10.2009; НПК 367/135.

10. Система видеонаблюдения за опасным участком магистрального газопровода: пат. 2334163 Российская Федерация, МПК F17D5/00, F16L55/26, G01M3/00 / Хоменко В.И., Винниченко С.А., Молчанов В.В. (РФ). № 2007105552/06; заявл. 14.02.2007; опубл. 20.09.2008.

11. Способ обнаружения места утечки или несанкционированного отбора нефти на линейной части магистрального нефтепровода: пат. 2273888 Российская Федерация, МПК7 G 08 В 25/10 \%F 17 D 5/02 / Ахметов Д.К., Кушнарев В.И., Соломонов Ю.С., Жирухин Ю.Н., Французов В.А. - № 2005131056/11; заявл. 07.10.2005; опубл. 10.04.2006. 
12. Geoplace - GEOEurope - Aerial imaging applications in pipeline industry [Электронный pecypc]. - URL: www.geoplace.com/ge/ 20016070160701pip.asp. (дата обращения: 12.05.2017).

13. Епифанцев Б.Н. Дистанционная диагностика подземных трубопроводов по тепловому излучению // Дефектоскопия. 2014. - № 3. - С. 28-39.

14. Ozevin Didem, Harding James. Novel leak localization in pressurized pipeline networks using acoustic emission and geometric connectivity // International Journal of Pressure Vessels and Piping. - 2012. - Vol. 92. - P. 63-69. DOI: 10.1016/2012.01.001

15. Epifantsev B.N. An acoustic method for diagnostics of the state of underground pipelines: new possibilities // Russian Journal of Nondestructive Testing. - 2014. - Vol. 50, № 5. P. 254-257. DOI: 10.1134/S1061830914050039

16. Epifantsev B.N., Pyatkov A.A., Fedotov A.A. Evaluation of the sensitivity of a vibroacoustic detection system for local disturbances of trunk pipeline environmental parameters // Russian Journal of Nondestructive Testing. 2015. - Vol. 51, № 2. - P. 70-78. DOI: 10.1134/S1061830915020035

17. Комаров B.А., Епифанцев Б.Н. Виброакустический контроль состояния магистральных продуктопроводов: адаптация к изменениям параметров окружающей среды // Комплексное обеспечение информационной безопасности автоматизированных систем: аннотированный сборник выпускных квалификационных работ ФГБОУ ВО «СибАДИ»; сост. 3.В. Семенова. - Омск. С. $38-45$.

18. Dollar P. et al. Pedestrian detection: an evaluation of the state of the art // IEEE Trans. on Pattern Analysis and Machine Intelligence. -
2012. - Vol. 34, № 4. - P. 743-761. DOI: 10.1109/TPAMI.2011.155

19. Епифанцев Б.Н., Пятков А.А., Копейкин С.А. Мультисенсорные системы мониторинга территорий ограниченного доступа: возможность видеоаналитического канала обнаружения вторжений // Компьютерная оптика. - 2016. - № 1. - С. 121-129.

20. Klar A., Linker R. Fiber optic sensing optical fibers detect tunnel-digging [Электронный pecypc] // Laser Focus World: Lasers, Photonics, Optics News \& Technology Advances, 2009. URL: http://www.laserfocusworld.com/articles/ print/volume-45/issue-4/world-news/fiber-opticsensing-optical-fibers-detect-tunnel-digging.html (дата обращения: 12.05.2017).

21. Duckworth G., Ku E. OptaSense (R) distributed acoustic and Seismic sensing using COTS fiber optic cables for Infrastructure Protection and Counter Terrorism // Sensors and command, control, communications and intelligence (c3i) Technologies for homeland security and homeland deference XII. 2013. - Vol. 8711. - № UNSP87110G. DOI: $10.1117 / 12.2017712$

22. Wang J. FBG intrusion recognition algorithm based on SVM // Advanced Materials Research. - 2012. - Vol. 591-593. - P. 1422-1427. DOI: 10.4028/www.scientific.net/AMR.591-593.1422

23. Волоконно-оптическая система мониторинга протяженных объектов (нефтепроводов) на основе когерентного рефлектометра / Е.Т. Нестеров, К.В. Марченко, В.Н. Трещиков, А.В. Леонов // Т-Comm. - 2014. - № 1. C. $25-28$.

24. Шеховцев А.В., Мансуров М.Н., Голубин С.И. Экспериментальные исследования волоконно-оптического метода обнаружения утечек из нефтепроводов // Трубопроводный транспорт: теория и практика. - 2015. № 6(52). - С. 30-35. 
25. Звежинский C.C. Проблема выбора периметровых средств // Специальная техника. 2002. - № 4. - С. 36-41.

26. Епифанцев Б.Н., Копейкин С.А. О вероятности обнаружения террористических угроз системами физической защиты магистральных трубопроводов // Динамика систем, механизмов и машин. - 2016. - Т. 1, № 2. - С. 246-252.

27. Епифанцев Б.Н., Пятков А.А. Предупреждение чрезвычайных ситуаций на магистральных продуктопроводах. Часть 1. Обнаружение несанкционированных вторжений в охранную хону продуктопровода. - Омск: СибАДИ, 2013. - 122 с.

28. Bass F.M. A new product growth for model consumer durables // Management Science. 1969. - P. 215-227. DOI: 10.1287/mnsc.15.5.215
29. Becker G.S. Crime and punishment: an economic approach // The Journal of Political Economy. - 1968. - Vol. 76, № 2. - P. 169-217. DOI: $10.1086 / 259394$

30. Корытина Е. Десять способов украсть нефть в России [Электронный ресурс] // РБК daily, 18.07.2011. URL: http://www.rbcdaily.ru/ 2011/07/18/tek/562959980660282 (дата обращения: 12.05.2017).

31. Информационно-аналитические материалы для заседания комиссии по противодействию незаконному обороту промышленной продукции в Самарской области, декабрь 2016 г. [Электронный ресурс]. - URL: http://samgd.ru/analytics/ notes/183926. (дата обращения: 12.05.2017). of terroristic threats: prognostic estimates. Perm Journal of Petroleum and Mining Engineering, 2018, vol.17, no.1, pp.88-100. DOI: $10.15593 / 2224-9923 / 2018.1 .8$

Просьба ссылаться на эту статью в русскоязычных источниках следующим образом:

Безопасность магистральных трубопроводов в условиях террористических угроз: прогнозные оценки / В.А. Комаров, 3.В. Семенова, Е.М. Михайлов, А.А. Нигрей, Д.А. Бронников // Вестник Пермского национального исследовательского политехнического университета. Геология. Нефтегазовое и горное дело. - 2018. - Т.17, №1. - С.88-100. DOI: $10.15593 / 2224-9923 / 2018.1 .8$ 